\title{
Correction to: Disagreement lost
}

\author{
Martín Abreu Zavaleta ${ }^{1}$
}

Published online: 20 November 2020

(c) The Author(s) 2020

\section{Correction to: Synthese https://doi.org/10.1007/s11229-020-02866-y}

The article Disagreement lost, written by Martín Abreu Zavaleta, was originally published electronically on the publisher's internet portal on 16 September 2020 without open access. The copyright of the article changed on 18 September 2020 to (C) The Author(s) 2020 and the article is forthwith distributed under a Creative Commons Attribution.

This article is licensed under a Creative Commons Attribution 4.0 International License, which permits use, sharing, adaptation, distribution and reproduction in any medium or format, as long as you give appropriate credit to the original author(s) and the source, provide a link to the Creative Commons licence, and indicate if changes were made.

The images or other third party material in this article are included in the article's Creative Commons licence, unless indicated otherwise in a credit line to the material. If material is not included in the article's Creative Commons licence and your intended use is not permitted by statutory regulation or exceeds the permitted use, you will need to obtain permission directly from the copyright holder.

To view a copy of this licence, visit http://creativecommons.org/licenses/by/4.0/.

Open Access This article is licensed under a Creative Commons Attribution 4.0 International License, which permits use, sharing, adaptation, distribution and reproduction in any medium or format, as long as you give appropriate credit to the original author(s) and the source, provide a link to the Creative Commons licence, and indicate if changes were made. The images or other third party material in this article are included in the article's Creative Commons licence, unless indicated otherwise in a credit line to the material. If material is not included in the article's Creative Commons licence and your intended use is not permitted by statutory regulation or exceeds the permitted use, you will need to obtain permission directly from the copyright holder. To view a copy of this licence, visit http://creativecommons.org/licenses/by/4.0/.

The original article can be found online at https://doi.org/10.1007/s11229-020-02866-y.

$凶 \quad$ Martín Abreu Zavaleta

martin.abreu@umu.se; maz275@nyu.edu

1 Department of Historical, Philosophical, and Religious Studies, Umeå universitet, A, Humanisthuset, HF127, 90187 Umeå, Sweden 
Publisher's Note Springer Nature remains neutral with regard to jurisdictional claims in published maps and institutional affiliations. 